\title{
Effect of Dietary Inclusion of Sieving Wastes of the Egyptian Clover Seeds Instead of Soybean Meal for Tilapia
}

Abdelhamid, A. M. ${ }^{1^{*}}$; M. F. I. Salem ${ }^{2}$ and Kh. R. A. E. S. Rashed ${ }^{1}$

${ }^{1}$ Animal Production Department, Faculty of Agriculture, Mansoura University, Mansoura, Dakahlia

Governorate 35516, Egypt

${ }^{2}$ Aquaculture Research Unit, Sakha, Central Lab. of Aquaculture Research, Agricultural Research

Center, Ministry of Agriculture, Cairo, Egypt

*Corresponding author.

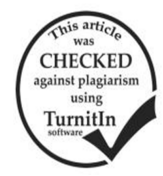

An indoor feeding experiment for 57 days was conducted on Nile tilapia to evaluate the effects of dietary inclusion of graded levels $(0,50,75$, and $100 \%)$ of sieving wastes meal of Egyptian clover seeds instead of soybean meal based on crude protein content. A total of 8 glass aquaria (each of $70 \times 35 \times 40 \mathrm{~cm}$, filled with $65 \mathrm{~L}$ dechlorinated tap water, and stocked with 12 fingerlings $17.3 \mathrm{~g}$ as average initial body weight and $9.5 \mathrm{~cm}$ as average total length) were used. The obtained results recommended the best replacement level of $50 \%$ which significantly realized the best feed composition, highest feed consumption, final body weight, and best body composition of Nile tilapia, to be reflected in many benefits for both the producers and the consumers.

Keywords: Clover seeds, sieving wastes, tilapia performance.

\section{INTRODUCTION}

Nowadays aquaculture in Egypt supplies ca. $80 \%$ of human fish consumption. Egypt occupies the tenth rank all over the world concerning aquaculture production (FAO, 2016). Nevertheless, the Aqua-feeds are shorter than the demands, besides their expensive costs; therefore, there is a need to recycle and reuse all possible and available field and industrial by-products that have a nutritional importance for fish (Koeleman, 2018a \& b). Since fish are the most feed converter than all terrestrial animal species (Shehab, 2018). However, adult tilapia is herbivores, omnivores, or detritovores (El-Sayed, 1991). Thus, many authors evaluated fish diets containing various agro-industrial wastes (El-Sayed, 1999) as fish meal, soybean meal, linseed meal, corn gluten, tomato waste, clover leaves, duck weed, poultry by-product meal, and bone and meat meal (Eid et al., 1995), sugar beet pulp (Magouz, 1996), lupine seed meal (Hassanen, 1998), corn gluten meal (El-Ebiary et al., 2001), black seed and roquette seed meals (Abd Elmonem et al., 2002), sunflower meal (El-Saidy and Gaber, 2002 a \& c), dried dropping dates (Srour et al., 2002), sugarcane bagasse compost (Hafez et al., 2003), sesame hulls by-product (Abd Elmonem et al., 2004), fennel seed meal, dried marjoram leaves, and dried basil leaves (El-Dakar et al., 2004 a, b, \& c, respectively), leaf protein concentrate from water hyacinth (El-Saidy et al., 2004), olive cake (Khalafalla and Salem, 2006), and silkworm meal (Salem et al., 2008) etc.... Therefore, the present research aimed to study the possibility of feeding Nile Table 1. Formulation of the experimental diets (Kg)

\begin{tabular}{lcccc}
\hline \multirow{2}{*}{ Ingredients } & \multicolumn{4}{c}{ Diets (replacement rate) No. } \\
\cline { 2 - 5 } & $\mathbf{1 ( 0 \% , \text { control) }}$ & $\mathbf{2}(\mathbf{5 0 \%})$ & $\mathbf{3}(\mathbf{7 5 \% )}$ & $\mathbf{4}(\mathbf{1 0 0} \%)$ \\
\hline Soybean meal (44\%,crude protein) & 320 & 160 & 100 & - \\
Ground wastes of sieving the Egyptian clover seeds & - & 200 & 300 & 400 \\
Fish meal & 40 & 40 & 40 & 40 \\
Gluten (62\%, crude protein) & 80 & 80 & 80 & 80 \\
Rice bran (12.5\%, crude protein) & 120 & 120 & 120 & 120 \\
Corn, fine ground (8\%, crude protein) & 400 & 360 & 320 & 320 \\
Plant oil & 20 & 20 & 20 & 20 \\
Broilers' concentrate & 20 & 20 & 20 & 20 \\
\hline Total & 1000 & 1000 & 1000 & 1000 \\
\hline
\end{tabular}

All dietary ingredients were purchased from the local market; where, the gluten (62\% crude protein) was purchased from Badamas Feed Factory belonging to Dakahlia Company for Poultry and rice bran (4000, 12.5\% crude protein) from the Rice Blower at Al-Gamal village, Mansoura. Corn (imported from Argentine) contained 8\% tilapia diets containing graded levels of sieving wastes meal of Egyptian clover seeds instead of soybean meal.

\section{MATERIALS AND METHODS}

Mono-sex Nile tilapia fingerlings (17.3g as average initial body weight and $9.5 \mathrm{~cm}$ as average total length) were purchased from a private hatchery at Tolombat 7, Kafr ElSheikh governorate. After transportation to Sakha Aquaculture Research Unit, Central lab. of Aquaculture Research, Abbasa, Abou Hammad, Sharqia governorate, Agricultural Research Center, Cairo; fish were adapted on the experimental lab. conditions for two weeks in a plastic tank of $1000 \mathrm{~L}$ capacity. Then distributed into eight glass aquaria, each volume of $70 \times 35 \times 40 \mathrm{~cm}$ stocked with 12 fingerlings, two aquaria / treatment. Aquaria were provided with $65 \mathrm{~L}$ dechlorinated tap water, electric air compressors, air stones and heaters with thermostats. Aquaria water was partially replaced with syphoning five times weekly and completely once a week. Rearing water criteria were periodically measured. Natural light was available $10 \mathrm{~h}$ daily. Four iso-nitrogenous $(25.36-25.92 \%$ crude protein) diets were formulated to contain the graded levels of sieving wastes meal of the Egyptian clover seeds instead of dietary soybean meal on basis of crude protein content. Table 1 illustrates formulation of the experimental diets. Diets 1, 2, 3, and 4 contained 25.92, 25.64, 25.36 and $25.36 \%$ calculated crude protein $(\mathrm{CP})$, respectively.

crude protein was purchased from Dakahlia Company for Poultry at Badamas, then was ground on $3 \mathrm{~mm}$ sieve at AlEzz factory of feeds. Broiler concentrate (Holman) was purchased from Dakahlia Company for Poultry at Badamas. It consists of mineral salts and vitamins as given in Table 2 . Diets were manually offered five days a week at daily 
feeding rate of $3 \%$ of the actual body weight of fish, at two meals daily 9 am and 12 mid-day. Fish were weighed biweekly to readjust feed quantity. Diets and whole fish body were chemically analyzed using AOAC (2000) procedures. Growth performance [body weight, total length, specific growth rate (SGR), relative growth rate (RGR), condition factor (Froese, 2006), and mortality rate] and feed utilization (feed intake and feed conversion ratio) were measured or calculated. All numerical data collected were statistically analyzed using SAS (2006) and Duncan (1955).

Table 2. Specifications and ingredients of Holman broiler concentrate $45 \%$ crude protein (Alpha Feed International, Al Obour Industrial Zone) Reg. No. 8813

\begin{tabular}{lc}
\hline Specifications & Ingredients \\
\hline Crude Protein $45 \%$ & Corn Gluten $60 \%$ \\
Crude Fiber $1.36 \%$ & Limestone \\
Crude Fat $1.38 \%$ & Mono Calcium Phosphate (2002) \\
Calcium $6.32 \%$ & Soya bean 48\% \\
Phosphorus available 2.33\% & L - Lysine Hydrochloride \\
Methionine 4\% & Salt \\
Methionine + Cystine 4.69\% & Vit.Mix. + Min. Mix. (4578) \\
Lysine 3.89\% & D - L - Methionine \\
Sodium 0.80\% & Choline Chloride (1309) \\
\hline Metabolizable Energy 2590 Kcal/kg
\end{tabular}

\section{RESULTS AND DISCUSSION}

\section{Some water quality criteria}

The rearing water criteria periodically measured from 19/11/2017 to 16/1/2018 did not differ among treatments or throughout the experimental period. Since water temperature ranged between 28.20 and $28.65^{\circ} \mathrm{C}, \mathrm{pH}$ 7.85-8.70, dissolved oxygen (DO) $9.10-9.85 \mathrm{mg} / \mathrm{L}$, total ammonia (T. amm.) $0.70-0.85 \mathrm{mg} / \mathrm{L}$, and salinity (Sal.) 1.20-1.55\%o (Table 3). These conditions are suitable for rearing Nile tilapia (Abd El- Hakim et al., 2002).

Table 3. Mean values of some quality criteria of the fish rearing water throughout the experimental period

\begin{tabular}{lccccc}
\hline Date & $\begin{array}{c}\text { Temp., } \\
{ }_{\mathbf{0}} \mathbf{C}\end{array}$ & $\mathbf{p H}$ & $\begin{array}{c}\mathbf{D O}, \mathbf{\text { mg/L }} \\
\mathbf{1 9}\end{array}$ & $\begin{array}{c}\text { T. amm/L } \\
\mathbf{m g} / \mathbf{L}\end{array}$ & $\begin{array}{c}\text { Sal., } \\
\mathbf{\% o}\end{array}$ \\
\hline $19 / 11 / 2017$ & 28.65 & 8.30 & 9.65 & 0.85 & 1.30 \\
$3 / 12 / 2017$ & 28.20 & 8.35 & 9.10 & 0.76 & 1.40 \\
$19 / 12 / 2017$ & 28.55 & 7.85 & 9.35 & 0.73 & 1.20 \\
$2 / 1 / 2018$ & 28.20 & 8.00 & 9.60 & 0.79 & 1.30 \\
$16 / 1 / 2018$ & 28.15 & 8.70 & 9.85 & 0.70 & 1.55 \\
\hline
\end{tabular}

Proximate analysis of the experimental diets

The gradual levels of the replacement (sieving wastes meal of the Egyptian clover seeds instead of soybean meal in the fish diets) significantly and gradually increased each of the dietary contents of dry matter, crude protein and carbohydrates; but significantly and gradually reduced the dietary contents of both ether extract and crude fibers (Table 4). These results are in partial agreement with those obtained by Abdelhamid and Saleh (2015) and Abdelhamid et al. (2016). It was proved that the increase of dietary CP increases significantly the body weight during certain physiological phases, and significantly and positively affects the RGR, as well as significantly influences each of feed intake and dry matter content of fish body (Abdelhamid et al., 2001 and Khalil et al., 2001).

Feed intake of the experimental fish

Feed intake by the experimental fish significantly differed by the dietary replacement levels. The highest feed intake $(\mathrm{P} \leq 0.01)$ was calculated for the fish group fed at $50 \%$ replacement comparing with the other replacement levels (Table 5). These currently findings are confirmed by those reported by Abo-Donia et al. (2004), Abdelhamid and Saleh (2015) and Abdelhamid et al. (2016) with some terrestrial animals.

Table 4. Mean values of the chemical analysis for the experimental diets, \% on dry matter basis

\begin{tabular}{lcccccc}
\hline Rep. \% & Moisture & CP & EE & CF & Carb. & Ash \\
\hline 0 & $29.14^{\mathrm{A}}$ & $25.15^{\mathrm{D}}$ & $13.16^{\mathrm{A}}$ & $12.92^{\mathrm{A}}$ & $26.78^{\mathrm{bB}}$ & $5.77^{\mathrm{C}}$ \\
50 & $26.82^{\mathrm{aB}}$ & $26.60^{\mathrm{C}}$ & $11.52^{\mathrm{B}}$ & $9.21^{\mathrm{B}}$ & $28.60^{\mathrm{aB}}$ & $6.44^{\mathrm{bB}}$ \\
75 & $25.78^{\mathrm{bB}}$ & $27.40^{\mathrm{B}}$ & $10.65^{\mathrm{C}}$ & $7.72^{\mathrm{C}}$ & $29.39^{\mathrm{aA}}$ & $6.78^{\mathrm{aB}}$ \\
100 & $24.84^{\mathrm{Bc}}$ & $28.09^{\mathrm{A}}$ & $9.88^{\mathrm{D}}$ & $5.78^{\mathrm{D}}$ & $30.06^{\mathrm{aA}}$ & $7.12^{\mathrm{aB}}$ \\
\hline
\end{tabular}

Rep.: replacement, CP: crude protein, EE: ether extract, CF: crude fibers, Carb.: carbohydrates. a-c: Mean in the same column superscripted with different small letters significantly differ $(\mathbf{P} \leq \mathbf{0 . 0 5})$. A-D: Mean in the same column superscripted with different capita letters significantly differ $(\mathbf{P} \leq \mathbf{0 . 0 1})$.

Table 5. Mean and standard errors of feed intake throughout the experimental period (g/fish / 57 days)

\begin{tabular}{lcc}
\hline Replacement levels, \% & Mean & Standard errors $( \pm)$ \\
\hline 0 & $23.20^{\mathrm{ab}}$ & 0.20 \\
50 & $25.35^{\mathrm{aA}}$ & 0.05 \\
75 & $23.85^{\mathrm{a}}$ & 0.55 \\
100 & $23.45^{\mathrm{ab}}$ & 0.25 \\
\hline
\end{tabular}

a: Means in the same column superscripted with the same small letter do not significantly differ $(\mathrm{P}>\mathbf{0 . 0 5})$. A-B: Means in the same column superscripted with different capita letters significantly differ $(\mathrm{P} \leq \mathbf{0 . 0 1})$.

\section{Final live body weight of the experimental fish}

Concerning the body weight of the experimental fish, there were no significant $(\mathrm{P}>0.05)$ differences among dietary treatments at the start of the experiment; yet, there were significant $(\mathrm{P} \leq 0.01)$ variations among treatments at the end of the experiment. Where, the final body weight of Nile tilapia fed dietary $50 \%$ sieving wastes meal of Egyptian clover seeds instead of soybean meal was significantly $(\mathrm{P} \leq 0.01)$ heavier than those of the other treatment groups (Table 6). This improvement in the final body weight of that treatment may be due to the significant increase in feed consumption of those group's fish (Table 5), whereas the lower final body weight of fish fed the two highest replacement levels (75 and $100 \%$ ) may be related to the significant high content of carbohydrates and crude fibers and significant low fat contents of their diets (Table 4). These results are in line with those documented by Abo-Donia et al. (2004), Abdelhamid and Saleh (2015) and Abdelhamid et al. (2016) although the variation among species of the experimental animals. In the same direction, replacement of $25 \%$ freshwater crab meal or $50 \%$ mixer (1/1) of duck weed meal with freshwater crab meal instead of fish meal in Nile tilapia diet led to the best final body weight, body weight gain, daily body weight gain, feed conversion rate, and economic efficiency, as well as the highest CP and the lowest EE of fish body and flesh ( Abdelhamid et al., 2009a \& b; 2011 and 2012b). In an another research field for feed evaluation of unconventional carbohydrate resources (one of agro-industrial by-products, i.e corn wastes of "Karata" manufacture) instead of corn in tilapia diets, the $100 \%$ replacement rate significantly succeeded; since, it was responsible for the best final body weight, body weight gain, daily body weight gain, RGR, SGR, feed intake, feed utilization, and fish body CP content (Abdelhamid et al., 2011). Moreover, in the field of recycling 
the agro-industrial by-products in fish feeding, Abdelhamid et al. (2015) proved that the distillers dried grains (DDGS) could be used in tilapia diets at $20 \%$ replacement level instead of fish meal to obtain the best growth performance; whereas, $100 \%$ replacement level led to the best economic efficiency. More recently, Khadr (2018) found that 30\% replacement rate of the DDGS did not negatively affect fish performance and health, but even improved the economic efficiency.

Table 6. Mean and standard errors of final body weight (g/fish) of the experimental fish

\begin{tabular}{lcc}
\hline Replacement level, \% & Mean & Standard errors ( \pm ) \\
\hline 0 & $33.05^{\mathrm{ab}}$ & 2.05 \\
50 & $45.50^{\mathrm{A}}$ & 2.50 \\
75 & $26.20^{\mathrm{ab}}$ & 1.60 \\
100 & $27.50^{\mathrm{ab}}$ & 2.70 \\
\hline
\end{tabular}

a: Mean in the same column superscripted with the same small letter do not significantly differ $(P>0.05)$. A-B: Mean in the same column superscripted with different capita letters significantly differ $(\mathrm{P} \leq \mathbf{0 . 0 1})$.

Growth rates of the experimental fish

Table 7 illustrates the response of the experimental fish to the dietary treatments tested in form of their growth rates. Throughout the experimental period, both of RGR and SGR negatively affected by all replacement levels, thus reflected lower values than the control $(0 \%$ replacement level). In an evaluation for plant protein sources, Abdelhamid et al. (2004a) reported that mallow (Malva parviflora L.) plants meal could replace $10 \%$ of the dietary protein as an alternative protein source for Nile tilapia (Oreochromis niloticus) fingerlings without negative effects on fish growth performance, fish muscular area, and economic efficiency. In another trial, Abdelhamid et al. (2004b) found that it was possible to replace $10 \%$ soybean meal protein by sesame meal protein in Nile tilapia fingerlings diet without any negative influences on growth performance, feed and nutrients utilization, and fish body composition. Moreover, it could partially (25-50\%) and successfully replaces soybean meal protein by black seeds (Nigella sativa) meal protein in Nile tilapia diet, which realized the best growth rates and economic efficiency when black seeds meal is available (Abdelhamid et al., 2005b). Water hyacinth protein could also partially (10-20\%) replace soybean meal protein realizing the best growth rates and economic efficiency (Abdelhamid et al., 2006). Yet, Abdelhamid et al. (2010a \& b) confirmed the opposite results; since the dietary inclusion of water hyacinth (particularly from polluted resources) negatively affected fish weight, their SGR, survival, feed conversion, and fish body composition. Consequently, they recommended to does not use water hyacinth from polluted water resources in fish nutrition, but when it is necessary and in case of feed shortage, it could be used only from uncontaminated resources and a maximum limit not exceed $30 \%$ of the dietary soybean meal protein. Although many people in Kafr El-Sheikh Governorate (as the highest governorate allover Egypt in producing fish) talk about sewage using in fish nutrition; yet, different freshwater fish species (Nile tilapia, silver carp, common carp, and African catfish) reflected low values of all tested measurements (growth, feed utilization, and fish body composition, dressing, and boneless meat) by their feeding with sewage comparing with those fed commercial-artificial diet. Thus, Abdelhamid et al. (2014) recommended do not feeding fish with treated sewage.
Table 7. Mean of RGR and SGR of the tested fish throughout the experimental period

\begin{tabular}{lcc}
\hline Replacement levels, \% & RGR, \% & SGR, \%/d \\
\hline 0 & 90.99 & 1.24 \\
50 & 53.50 & 0.63 \\
75 & 58.25 & 0.60 \\
100 & 60.35 & 1.00 \\
\hline
\end{tabular}

Final total length and condition factor of the experimental fish

The calculated condition factor (CF) of the experimental fish at the start of the experiment was $2.018 \%$, since the initial body weight and total length were $17.3 \mathrm{~g}$ and $9.5 \mathrm{~cm}$, respectively. Values of final total length and CF of the experimental fish (Table 8) revealed no significant $(\mathrm{P}>0.05)$ differences among treatments; yet, fish fed the $50 \%$ replacement diet gave superior $\mathrm{CF}(2.33 \%)$ than all other treatments. This superiority of $\mathrm{CF}$ with that diet may be due to the significant highest final body weight of fish in that treatment (Table 6) than with all other treatments. Sieving wastes of Egyptian clover (berseem) seeds were rarely used in animal nutrition (Abo-Donia et al., 2004; Abdelhamid and Saleh, 2015 and Abdelhamid et al., 2016), but there is no available data about its use in fish nutrition. Generally, in the field of using novel (unconventional) feeds, dried live yeast as a source of mono-cellular protein was used with/or without LactoSac $^{\circledR}$ (as a commercial probiotic) in Nile tilapia diets. Its mixture (at a level of $20 \mathrm{~g} / \mathrm{Kg}$ diet) was significantly improved the weight, length, $\mathrm{CF}$, and feed utilization of fish (Abdelhamid et al., 2000).

Table 8. Mean of the final total length and condition factor of the experimental fish (each value is the mean of 8 fishes)

\begin{tabular}{lcc}
\hline $\begin{array}{l}\text { Replacement levels, } \\
\text { \% }\end{array}$ & $\begin{array}{c}\text { Final total } \\
\text { length, cm }\end{array}$ & $\begin{array}{c}\text { Condition factor, } \\
\text { \% }\end{array}$ \\
\hline 0 & 13.69 & 1.29 \\
50 & 12.50 & 2.33 \\
75 & 12.75 & 1.26 \\
100 & 12.50 & 1.41 \\
\hline
\end{tabular}

Feed conversion ratio of the experimental fish

Although the significant elevation of the feed intake by fish in the treatment offered the 50\%-replacement diet; yet, it reflected the best feed conversion ratio (FCR) (0.90), since it gave the significant highest final body weight than all other treatments. The values of FCR were 1.47, 0.90, 2.68, and 2.30 for the diets included 0, 50, 75, and $100 \%$ replacement levels, respectively. Feed evaluation process continued, Abdelhamid et al. (2005a) successfully replaced till $50 \%$ of soybean meal protein by linseed meal protein in Nile tilapia diets and obtained improved growth, FCR, nutrients utilization, fish body protein content, and economic efficiency.

Chemical analysis of the whole fish body at the end of the experiment

Table 9 presents mean values of the chemical composition of the whole body of Nile tilapia at the end of the experimental period. There is a gradual and significant $(\mathrm{P} \leq 0.01)$ decrease in moisture percentage, i.e. increase in dry matter content in fish body by increasing the replacement level. This led to significant $(\mathrm{P} \leq 0.01)$ increase in $\mathrm{CP}$ and ash contents by the increase of replacement percentage. The opposite was true, concerning EE that significantly $(\mathrm{P} \leq 0.01)$ decreased with increasing the replacement rate. In this respect, Hassanen et al. (1995) reported that increasing levels 
of some fermented waste foods (tomato pulp silage) in diets reduced lipid content, but increased ash content in whole fish body as that found in the present work. Also, Kheir and Sweilum (1997) stated that increasing dietary CP content led to increase fish body $\mathrm{CP}$ and decrease its ash content. Since the negative relationship between $\mathrm{CP}$ and $\mathrm{EE}$ is a fact (ElSaidy and Gaber, 1997, 2002b \& 2005; Hassanen, 1998; Abd Elmonem et al., 2002; Azab et al., 2002; Gaber, 2002a \& b \& 2006; Zaki and El-Ebiary, 2003; El-Dakar et al., 2004b; Gaber and Hanafy, 2004; Abdelhamid et al., 2006, 2009b, 2011, 2012b, \& 2015; Diab et al., 2006; Hanafy, 2006; Soltan et al., 2006; Saad, 2007 \& 2010; Ali, 2008; Salem et al., 2008 and Farrag et al., 2013). Although other researchers reported positive correlation between fish body CP and EE (Kheir and Sweilum, 1997; Mabrouk et al., 2000; Soltan et al., 2001; El-Saidy and Gaber, 2002a \& b; El-Sayed, 2003; Shalaby et al., 2003; El-Dakar et al., 2004a \& b; El-Saidy and Gaber, 2004; Nour et al., 2004; Ayaad and Hassouna, 2005a \& b; Gaber, 2005; Eweedah et al., 2006 and Soltan et al., 2008); but others (Mohamed and Hanafy, 2002; Soltan, 2002; Soltan et al., 2002 and El-Dakar, 2004) found no effect on fish chemical composition due to dietary treatments.

However, carbohydrates did not significantly influence by the dietary treatments. The improvement in chemical composition of the whole fish body (concerning CP content) may be attributed to the increase of dietary $\mathrm{CP}$ content with increasing the replacement level (Table 4). By evaluating medicinal plants in fish nutrition, Abdelhamid and Soliman (2012a \&c) obtained significant improvement in Nile tilapia utilization of energy and protein of the diets included fenugreek seeds or Cresson seeds at 1-2\% levels, thus the growth rates and fish body protein increased. Also, Abdelhamid and Soliman (2012d) recommended the dietary inclusion of $2 \%$ dried guava leaves or camphor trees for its improving effects on growth performance, feed utilization, and fish body composition. Additionally, Abdelhamid and Soliman (2013) also recommended the addition of $1-2 \%$ of the common carp diets either of Mentha arvensis leaves meal, Camellia sinesis leaves meal, Marticaria chmomilla meal, Origanum majorana leaves meal, Zingiber officinale meal, or Cinnamum zeylanicum meal (according to its availability and prices to preserve fish production economy), because its beneficial roles in improving growth performance, feed and nutrients utilization, and fish body composition. On the other hand, Magouz (1996) found that dietary inclusion of sugar beet pulp did not influence Nile tilapia body composition.

Table 9. Mean of chemical analysis of whole body of the experimental fish at the end of the experiment (\% on fresh weight basis)

\begin{tabular}{lccccc}
\hline Rep., \% & Moisture & CP & EE & Ash & Carb. \\
\hline 0 & $75.23^{\mathrm{A}}$ & $17.10^{\mathrm{C}}$ & $3.52^{\mathrm{A}}$ & $1.66^{\mathrm{bC}}$ & 2.48 \\
50 & $74.54^{\mathrm{B}}$ & $18.02^{\mathrm{cB}}$ & $3.01^{\mathrm{ab}}$ & $2.13^{\mathrm{aC}}$ & 2.27 \\
75 & $73.63^{\mathrm{C}}$ & $18.81^{\mathrm{ab}}$ & $2.43^{\mathrm{ab}}$ & $2.72^{\mathrm{B}}$ & 2.39 \\
100 & $72.95^{\mathrm{D}}$ & $19.70^{\mathrm{aA}}$ & $1.96^{\mathrm{C}}$ & $3.17^{\mathrm{A}}$ & 2.21 \\
\hline
\end{tabular}

Rep.: replacement, Carb.: carbohydrates. a-c: Mean in the same column superscripted with different small letters significantly differ (P $\leq$ 0.05). A-D: Mean in the same column superscripted with different capita letters significantly differ $(P \leq 0.01)$.

\section{CONCLUSION}

From the foregoing results, it could conclude and recommend the best replacement level of $50 \%$ (sieving wastes meal of Egyptian clover seeds instead of soybean meal based on crude protein) which significantly realized the best feed composition, highest feed consumption, final body weight, and best body composition of Nile tilapia, that may be reflected in many benefits for both the producers and the consumers.

\section{REFERENCES}

Abd El- Hakim, N. F.; M. N. Bakeer and M. A. Soltan (2002). Water Environment for Fish Culture. Deposition NO: 4774, ISBN: 977-298-228-5.

Abd Elmonem, A.; S.M.M. Shalaby and A.Y. El-Dakar (2002). Response of red tilapia to different levels of some medicinal plants by-products: black seed and roquette seed meals. Proc. $1^{\text {st }}$ Sc. Conf. Aqua., ElArish, 13-15 Dec., pp: 247-260.

Abd Elmonem, A.; S.M.M. Shalaby, A.Y. El-Dakar and O.W. Sadrak (2004). Nutritional evaluation of sesame hulls by-product as a non-conventional feedstuff in diets of red tilapia, Oreochromis niloticus $\times$ Oreochromis mosambicus. Alex. J. Agric. Res., 49 (2): 1-13.

Abdelhamid, A. M. and A. A. A. Soliman (2012a). Possibility of using medicinal plants in fish diets: IIICresson seeds. J. Animal and Poultry Production, Mansoura University, 3: 319-327.

Abdelhamid, A. M. and A. A. A. Soliman (2012b). Possibility of using medicinal plants in fish diets: IVCamphor dried leaves. J. Animal and Poultry Production, Mansoura University, 3: 329-338.

Abdelhamid, A. M. and A. A. A. Soliman (2012c). Possibility of using fenugreek seeds or cresson seeds in tilapia diets. Journal of the Arabian Aquaculture Society, 7 (1): $75-90$.

Abdelhamid, A. M. and A. A. A. Soliman (2012d). Possibility of using dried leaves of guava and camphor trees in tilapia diets. Journal of the Arabian Aquaculture Society, 7 (1): 91 - 108.

Abdelhamid, A. M. and A. A.A. Soliman (2013). Comparative evaluation for dietary inclusion of some medicinal plants by common carp fish. Egyptian J. Nutrition and Feeds, 16 (2): 485-499.

Abdelhamid, A.M. and M.T.M. Saleh (2015). Evaluation of substituting the sieving wastes of Egyptian clover's seeds instead of soya bean in the diet of Flan-line rabbits. J. Animal and Poultry Prod., Mansoura Univ., 6 (3): 137-147.

Abdelhamid, A.M.; A.A. El-Shebly and A. S. I. Sultan (2015). Effect of dietary graded levels of substituting distillers dried grains with solubles instead of fish meal in tilapia diet. J. Animal and Poultry Prod., Mansoura Univ., 6 (7): 441-457.

Abdelhamid, A. M.; A. A. A. Soliman and N. A. Maghraby (2011). Effect of replacing yellow corn via corn byproduct in tilapia fingerlings diet. Egyptian $\mathrm{J}$. Nutrition and Feeding, 14 (3): 547-556.

Abdelhamid, A. M., F. F. Khalil and M. E. A. Mostafa (2001). Nutritional influences on Nile tilapia (Oreochromis niloticus) broodstock. 4- Growth performance of fry. $2^{\text {nd }}$ Inter. Conf. on Anim. Prod. \& Health in Semi-Arid Areas. El- Arish, 4 - 6 Sept., pp: $645-654$

Abdelhamid, A. M., F. F. M. Khalil and M. A. A. Seden (2000). Possibility of using dried live yeast and lacto-sacc in Nile tilapia fingerlings' diets. J. Agric. Sci. Mansoura Univ., 25: 4905-4911. 
Abdelhamid, A. M.; F. I. Magouz, M. I. B. El-Mezaien, A. E. Abd El-Khalik, M. M. El-Sayed Khlaf Allah and E. M. O. Ahmed (2010a). Effect of source and level of dietary water hyacinth on Nile tilapia Oreochromis niloticus- Histopathology. engormix. com, Aquaculture Technical Article, $19 \mathrm{p}$.

Abdelhamid, A. M.; F. I. Magouz, M. I. B. El-Mezaien, M. M. El-S. Khlafallah and E. M. O. Ahmed (2010b). Effect of source and level of dietary water hyacinth on Nile tilapia, Oreochromis niloticus, performance. J. of Animal and Poultry Production, Mansoura University, 1 (4): $133-150$.

Abdelhamid, A. M., M. F. I. Salem, and A. E. Tolan (2005a). Evaluation of linseed meal as feed ingredient in diets on growing Nile tilapia (Oreochromis niloticus). J. Agric. Res. Tanta Univ., 31 (3): $385-402$.

Abdelhamid, A. M., M. F. I. Salem, and A. E. Tolan (2005b). Utilization of black seed meal (Nigella sativa) in Nile tilapia (Oreochromis niloticus) diets. J. Agric. Res. Tanta Univ., 31 (3): 403 - 419.

Abdelhamid, A. M.; M. F. I. Salem and M. M. E. Khalafalla (2006). Substitution of soybean meal by water hyacinth hay in diets of Nile tilapia (Oreochromis niloticus). The $2^{\text {nd }}$ Inter. Sci. Con. For Environment "Recent Environmental Problems and Social Sharement", 28-30 March, South Valley University. Pp: $114-126$.

Abdelhamid, A. M.; M. F. I. Salem, and A. E. Tolan (2004a). Evaluation of mallow (Malva parviflora L.) plants as an alternative protein source for Nile tilapia (Oreochromis niloticus) fingerlings. J. Agric. Sci. Mansoura Univ., 29: 6899 - 6910.

Abdelhamid, A. M.; M. F. I. Salem, and A. E. Tolan (2004b). Evaluation of sesame meal as a dietary protein source for Nile tilapia (Oreochromis niloticus) fingerlings. J. Agric. Sci. Mansoura Univ., 29: $6887-6897$.

Abdelhamid, A.M.; M.M. Refaey, I.H. Mekled and S.I.M. Grawish (2014). Possible effects of feeding fish the dried treated sewage sludge: I- concerning growth performance, feed utilization and chemical composition. J. Animal and Poultry Prod., Mansoura Univ., 5 (10): 563-582.

Abdelhamid, A. M.; N. A. Maghraby, A. I. Mehrim and A. A. A. Soliman, (2010c). Evaluation of dietary substitution with duckweed and/or freshwater crayfish instead of fishmeal in diets for Nile tilapia fish. engormix.com, Aquaculture Technical Articles, $17 \mathrm{p}$.

Abdelhamid, A. M.; N. A. Maghraby, A. I. Mehrim, A. A. A. Soliman and H. M. Ali (2012a). Impact of nonconventional feedstuffs on dietary composition and growth performance and nutrients utilization of Nile tilapia fish. Proc. of the $13^{\text {th }}$ Sci. Conf. for Animal Nutrition, 14-17 Feb., Sharm El-Shekh, pp: 349-357.

Abdelhamid, A. M.; N. A. Maghraby, A. I. Mehrim, A. A. A. Soliman and H. M. Ali (2012b). Physiological, biochemical and microbiological assessment for nonconventional feedstuffs by Nile tilapia fish. Proc. of the $13^{\text {th }}$ Sci. Conf. for Animal Nutrition, 14-17 Feb., Sharm El-Shekh, pp: 359-366.
Abdelhamid, M. A.; N. A.Maghraby, A. I. Mehrim, A. A. A. Soliman and H. M. Ali (2009a). Evaluation of some non-conventional diets for Nile tilapia fish. Iconcerning dietary composition, water quality, growth performance, and nutrients utilization of the fish. J. Agric. Sci. Mansoura Univ., 34: 10977 10990.

Abdelhamid, M. A.; N. A. Maghraby, A. I. Mehrim, A. A. A. Soliman and H. M. Ali (2009b). Evaluation of some non-conventional diets for Nile tilapia fish. IIConcerning blood profile and chemical composition of fish. J. Agric. Sci. Mansoura Univ., 34: 10991 10999

Abdelhamid, A.M.; R. F. S. A. Ismail and M. T. M. Saleh (2016). Evaluation of complete substitution of sieving wastes of the Egyptian clover seeds instead of soybean meal and maize in rabbit's diet. J. Animal and Poultry Prod., Mansoura Univ., 7 (5): 153-162.

Abo-Donia, F.M.A.; U.A. El-Zalaki and A.H. Mohamed (2004). Effect of using screening berseem seed as a source of protein instead of linseed meal in fattening lamb rations. J. Agric. Sci. Mansoura Univ., 29 (3): 1077-1089.

Ali, B.A. (2008). Effect of total replacement of fish meal by plant protein source and amecozyme on growth performance and feed utilization of monosex Nile tilapia (Oreochromis niloticus) fingerlings. Egtpt. J. of Appl. Sci., 23 (7): 13-24.

AOAC (2000). Association of Official Analytical Chemists of Official Methods of Analysis. 17 ${ }^{\text {th }}$ Ed., Washington, DC.

Ayaad, E.A. and M.M.E. Hassouna (2005a). Effect of replacing soybean meal by poultry industry wastes on growth performance of seabass, Dicentrarchus labrax, reared in earthen ponds. J. Egypt. Acad. Soc. Environ. Develop., (D-Environmental Studies), 6 (2): 247-255.

Ayaad, E.A. and M.M.E. Hassouna (2005b). Effect of partial replacement of fishmeal by poultry industry wastes in diets on growth performance of seabass, Dicentrarchus labrax, reared in earthen ponds. J. Egypt. Acad. Soc. Environ. Develop., (DEnvironmental Studies), 6 (2): 257-266.

Azab, M.E.; S.I. Fathalla and M.A. Soltan (2002). Effect of feed supplementation with L-carnitine on growth performance and body composition of Nile tilapia (Oreochromis niloticus). SCVMJ, V (1): 201-214.

Diab, A.S; Y.M. Abdel-Hadi, M.H. Ahmad, S.F. Sakr and M.E. Abo El-Atta (2006). Outdoor study on the use of Echinacea (Echinacea purperea), marjoram (Origanum majorana) and yeast (Saccharomyces cerevisiae) as feed additives for Oreochromis niloticus. Egypt. J. Agric. Res., 84 (1B): 537-551.

Duncan, D.B. (1955). Multiple ranges and multiple F-tests. Biometrics, 11: 1-42.

Eid, A.E.; M.A. Danasoury, F.Z. Swidan and K.A. El-Sayed (1995). Evaluation of twelve practical diets for fingerlings Nile tilapia (Oreochromis niloticus). Proc. $5^{\text {th }}$ Sci. Conf. Animal Nutrition, Vol. 1: 345353, Ismailia, Dec. 
El-Dakar, A.Y. (2004). Growth response of hybrid tilapia, Oreochromis niloticus $\times$ Oreochromis auraus, fingerlings to diets supplemented with different levels of caraway seeds. J. Agric. Sci. Mansoura Univ., 29 (11): 6083-6094.

El-Dakar, A.Y.; G.D.I. Hassanien, S.S. Gad and S.E. Sakr (2004a). Medicinal and aromatic plants as feeding attractants for fish. 1-Effect of dried marjoram leaves on performance of hybrid tilapia, Oreochromis niloticus $\times$ Oreochromis aureus, fingerlings. J Egypt. Acad. Soc. Environ. Develop., (B-Aquaculture), 5 (1): 67-83.

El-Dakar, A.Y.; G.D.I. Hassanien, S.S. Gad and S.E. Sakr (2004b). Medicinal and aromatic plants as feeding attractants for fish. 1-Effect of dried basil leaves on performance of hybrid tilapia, Oreochromis niloticus $\times$ Oreochromis aureus, fingerlings. $3^{\text {rd }}$ Con. on Anim., Poul. \& Fish Prod. and Health in Semi-Arid Areas, 7-9 Sept. El-Arish, pp: 265-277.

El-Ebiary, E.H.; M.A. Zaki and H.A. Mabrook (2001). The use of corn gluten meal as a partial replacement for fish meal in diets of sea bass (Dicentrarchus labrax) fry. Bull. Nat. Inst. of Oceanogr. \& Fish., A.R.E., 27: 373-386.

El-Saidy, D.M.S.D. and M.M.A. Gaber (1997). Effect of different levels of dry garlic meal supplemented to the diets on growth performance, survival and body composition of Nile tilapia (Oreochromis niloticus) fingerlings. Annals of Agric. Sc., Moshtohor, 35 (3): 1197-1209.

El-Saidy, D.M.S.D. and M.M.A. Gaber (2002a). Evaluation of hulled sunflower meal as a dietary protein source for Nile tilapia, Oreochromis niloticus (L), fingerlings. Annals of Agric. Sc., Moshtohor, 40 (2): 831-841.

El-Saidy, D.M.S.D. and M.M.A. Gaber (2002b). Evaluation of dehulled sunflower meal as a partial and complete replacement for fish meal in Nile tilapia, Oreochromis niloticus (L), diets. Proc. $1^{\text {st }}$ Ann. Sc. Conf. Anim. \& Fish Prod. Mansoura 24 \& 25 Sep., 193-205.

El-Saidy, D.M.S.D. and M.M.A. Gaber (2002c). Intensive culture of Nile tilapia, Oreochromis niloticus in concrete tanks in Egypt: effect of stocking density and feeding levels on growth performance, production traits, feed conversion and body composition. Proc. $1^{\text {st }}$ Sc. Conf. Aqua., El-Arish, 1315 Dec., pp: 1-22.

El-Saidy, D.M.S.D. and M.M.A. Gaber (2004). Effect of yucca (Yucca shidigera) on water quality and growth performance of Nile tilapia (Oreochromis niloticus L.) fingerlings. Egypt. J. Aquat. Biol. \& Fish., 8 (!): 33-50.

El-Saidy, D.M.S.D. and M.M.A. Gaber (2005). Effect of dietary protein levels and feeding rates on growth performance, production traits and body composition of Nile tilapia, Oreochromis niloticus (L.) cultured in concrete tanks. Aquaculture Research, 36: 163-171.

El-Sayed, A.-F.M. (1991). Tilapia nutrition in aquaculture. Reviews in Aquatic Sciences, 5 (3-4): 247-265.

El-Sayed, A.-F.M. (1999). Alternative dietary protein sources for farmed tilapia, Oreochromis spp. Aquaculture, 179: 149-168.
El-Sayed, A.-F.M. (2003). Effects of fermentation methods on the nutritive value of water hyacinth for Nile tilapia Oreochromis niloticus (L.) fingerlings. Aquaculture, 218: 471-478.

Eweedah, N.M.; E.M. Abd El-Raouf, M.F.I. Salem, M.M.E. Khalafalla and B.S. Abd El-Aty (2006). Replacement of fish meal by fresh water crayfish meal (Procombrus clarkii) in practical diets for Nile tilapia (Oreochromis niloticus). Egypt. J. Agric. Res., 84 (1B): 325-338.

FAO (2016). Status of Fish Resources and Aquaculture in the World. Rome, Italy.

Farrag, F.H.; F.F. Khalil, A.I. Mehrim and M.M.A. Refaey (2013). Pawpaw (Carica papaya) seeds powder in Nile tilapia (Oreochromis niloticus) diet. 1- growth performance, survival, feed utilization, carcass composition of fry and fingerlings. J. Animal and Poultry Prod., Mansoura Univ., 4 (6): 363-379.

Froese, R. (2006). Cube law, condition factor and weightlength relationship: history, met at analysis and recommendations. J. Applichthyol., 22 (4): 241-253.

Gaber, M.M. (2002a). Effects of dietary carbohydrate-tolipid ratios on growth performance and body composition of Nile tilapia, Oreochromis niloticus (L.), fingerlings. Egypt. Aquat. Biol. \& Fish., 6 (2): 25-40.

Gaber, M.M. (2002b). The effect of different levels of krill meal supplementation of soybean-based diets on feed intake, digestibility, and chemical composition of juvenile Nile tilapia, Oreochromis niloticus L. Journal of the World Aquaculture Society, 36 (3): 325-332.

Gaber, M.M. (2006). The effects of plant-protein-based diets supplemented with yucca on growth, digestibility, and chemical composition of Nile tilapia (Oreochromis niloticus, L.) fingerlings. Journal of the World Aquaculture Society, 37 (1): 1-8.

Gaber, M.M. and M.A. Hanafy (2004). Effect of yucca (Yucca shidigera) on water quality, growth performance and digestibility in common carp fry, Cyprinus carpio (L). J. Egypt. Acad. Soc. Environ. Develop., (B-Aquaculture), 5 (1): 111-126.

Hafez, F.A.; S.A. Arafa, G.M. Abdul-Aziz, A. A. Hassan and M.M. Abd El-Aal (2003). Effect of commercial diets, manure and some agriculture by-products on performance of Nile tilapia in polyculture system. Egyptian Soc. Anim. Reprod. Fert., Fifteen Annual Cong., Quena and Luxor, 26-30 January, pp: 195208.

Hanafy, M.A. (2006). Effect of replacement of soybean meal by linseed meal on growth performance and body composition of the Nile tilapia, Oreochromis niloticus (L.) cultured in concrete ponds. Egypt. J. Aquat. Biol. \& Fish., 10 (3): 185-200.

Hassanen, G.D.I. (1998). Lupine seed meal compared with soybean meal as partial substituted for fish meal in gilthead sea bream (Sparus aurata) diets. J. Agric. Sci. Mansoura Univ., 23 (1): 141-154.

Hassanen, G.D.I.; M.A. Sherif, H.A. Hashem and M.A. Hanafy (1995). Utilization of some fermented waste food as a protein source in pelleted feeds for Nile tilapia (Oreochromis niloticus) fingerlings. Proc. $5^{\text {th }}$ Sci. Conf. Animal Nutrition, Vol. 1: 427-435, Ismailia, Dec. 
Khadr, M.M.E.A. (2018). Using of distillers dried grains with solubles in Nile tilapia fish diet. M.Sc. Thesis, Faculty of Agriculture, Zagazig University, Egypt.

Khalafalla, M.M.E. and M.F.E. Salem (2006). Use of (olive cake, sugar beet pulp and molasses) as nonconventional energy feed sourced in Nile tilapia (Oreochromis niloticus) diets. Egypt. J. Agric. Res., 84 (1B), 295-309.

Khalil, F. F., A. M. Abdelhamid and M. E. A. Mostafa (2001). Nutritional influences on Nile tilapia broodstock fish (Oreochromis niloticus). 1- Growth performance and feed utilization. Egypt. J. Nutr. and Feed, 4: $685-693$.

Kheir, M.T. and M.A. Sweilum (1997). Effect of different dietary protein levels on the growth, survival rate and body composition of fry Oreochromis niloticus. Bull. Fac. Sci., Zagazig Univ., 19 (1): 274-286.

Koeleman, E. (2018a). Stop using the word 'waste'. AllAboutFeed, 26 (6): 5.

Koeleman, E. (2018b). We have to restart the blue revolution. AllAboutFeed, 26 (6): 7-8.

Mabrouk, H.A.; A.M. Nour, M.A. Zaki and A.R. Abou Akkada (2000). Effect of dietary replacement of fresh water shrimp meal instead of fish meal on growth performance, feed and nutrient utilization and carcass composition of Sparus aurata. Proc. $3^{\text {rd }}$ All Africa Conf. Anim. Agric. \& $11^{\text {th }}$ Conf. Egyptian Soc. Anim. Prod., Alexandria, Egypt. 6-9 Nov., pp.: 317-324.

Magouz, F.I. (1996). Effect of including sugar beer pulp in the diet of growth performance, efficiency of feed utilization and body composition of Nile tilapia (Oreochromis niloticus). J. Agric. Sci. Mansoura Univ., 21 (1): 187-193.

Mohammed, R.A. and M.A. Hanafy (2002). Effect of dietary protein and energy levels on growth and body composition of Oreochromis niloticus (L) and Cyprinus carpio (L). Proc. $1^{\text {st }}$ Sc. Conf. Aqua., ElArish, 13-15 Dec., p: 217-233.

Nour, A.A.; T.M. Srour and O. Nour (2004). Utilization of inedible dried dropping dates as a dietary energy source for blue tilapia (Oreochromis aureus) reared in enclosure nets. J. Agric. Sci. Mansoura Univ., 29 (1): $73-82$.

Saad, A.S. (2007). Effect of replacing fish meal with soybean meal on growth and body composition of grass carp "Ctenopharyngodon idella". Egypt. J. Aquat. Biol. \& Fish., 11 (3): 1329-1341.

Saad, A.S. (2010). Effect of fermented diets on growth, body composition and survival of Nile tilapia "Oreochromis niloticus". J. Egypt. Ger. Soc. Zool., 61A: Comparative Physiology, 49-62.
Salem, M.F.I.; M/M/E. Khalafalla, I.A.I. Saad and A.M.A. El-Hais (2008). Replacement of fish meal by silkworm, Bombyx mori pupae meal, in Nile tilapia, Oreochromis niloticus diets. Egyptian J. Nutrition and Feeds, 11 (3): 611-624.

SAS (2006). SAS/STAT Guide for personal computer. SAS Inst. Cary, N. C.

Shalaby, S.M.M.; A.I. Abd Elmonem, A.Y. El-Dakar and O.W. Wahbi (2003). Improvement of growth and feed utilization by using licorice roots (Erksous) as a feed additive in diets of Nile tilapia, Oreochromis niloticus fingerlings. J. Egypt. Acad. Soc. Environ. Develop., (B-Aquaculture), 4 (2): 119-142.

Shehab, M. (2018). His page on Facebook.

Soltan, M.A. (2002). Using of tomato and potato byproducts as non-conventional ingredients in Nile tilapia, Oreochromis noliticus diets. Annals of Agric. Sc., Moshtohor, 40 (4): 2081-2096.

Soltan, M.A.; A.A. Radwan and I.M. Samra (2002). Effect of varying protein, energy and protein to energy ratio on growth, feed efficiency and body composition of Nile tilapia, Oreochromis niloticus. The $1^{\text {st }}$ Annual Conference of the Egyptian Aquaculture Society, AlArish, north Sinai, Egypt, 13-15 December, p: 1-17.

Soltan, M.A.; K.A. Mohamed and A.H. Eid (2006). Effect of protein to energy ratio on growth performance and body composition of red tilapia reared in freshwater. Journal of the Egyptian Aquaculture Society, 1; 5768.

Soltan, M.A.; M.A. Hanafy and M.I.A. Wafa (2008). An evaluation of fermented silage made from fish byproducts as a feed ingredient for African catfish (Clarias gariepinus). Global Veterinaria, 2 (2): 8086.

Soltan, M.A.; M.K. Ibrahim, F.A. Hafez and A.F. Fath ElBab (2001). Effect of partial and total replacement of fish meal by soybean meal on growth and proximate analysis of Nile tilapia (Oreochromis niloticus). Egyptian J. Nutrition and Feeds, 4 (Special Issue): 799-812.

Srour, T.M.A.; M.A. Zaki and A.A. Nour (2002). Dried dropping dates (DDD) as a dietary source for Nile tilapia (Oreochromis niloticus) and African catfish (Clarias gariepinus). Proc. $1^{\text {st }}$ Ann. Sc. Conf. Anim. \& Fish Prod. Mansoura 24 \& 25 Sep., pp: 183-192.

Zaki, M.A. and E.H. El-Ebiary (2003). Effect of incorporation of onion and garlic into diets on growth performance and body composition of monosex Nile tilapia (Oreochromis niloticus). Egypt. J. Aqut. Biol. \& Fish., 7 (1): 113-126.

\footnotetext{
تأثير محتوى العليقة من مخلفات غربلة بذور البرسيم المصرى كبديل لكسب فول الصويا للبلطى

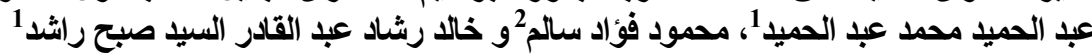

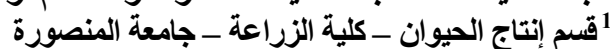

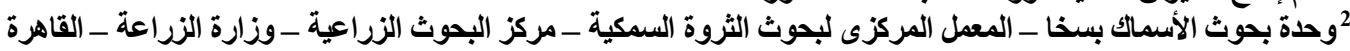

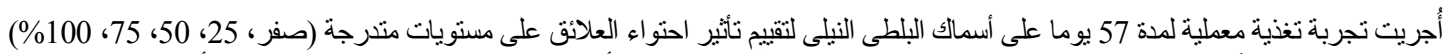

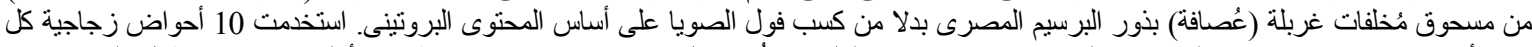

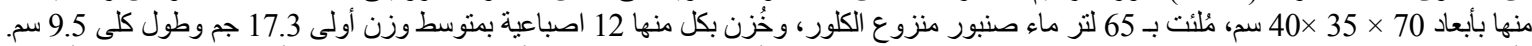

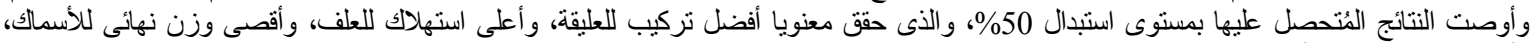
و أفضل تركيب جسم للأسماك، مما ينعكس بدون شك بالعديد من الفو ائد على كل من المنتجين و المستهلكين.
} 